\title{
Effect of Drying Temperatures on the Peanut Quality during Hot Air Drying
}

\author{
Chenling $\mathrm{Qu}^{1 *}$, Xueke Wang ${ }^{1}$, Ziwei Wang ${ }^{1}$, Songcheng $\mathrm{Yu}^{2}$, and Dianxuan Wang ${ }^{1 *}$ \\ ${ }^{1}$ College of Grain Oil and Food Science, Henan University of Technology, Zhengzhou 450001, China \\ ${ }^{2}$ College of Public Health, Zhengzhou University, Zhengzhou 450001, CHINA
}

\begin{abstract}
Peanuts are usually with high moisture after harvest and must be dried to prevent mildew. Hot air drying is the most commonly used method for peanut drying. The purpose of this study was to evaluate the drying temperatures on the peanut qualities. In this paper, fresh peanuts were dried with solar radiation (control group) and hot air at $35-60^{\circ} \mathrm{C}$ until the moisture content of peanut reduced below $10 \%$. The physical (texture, damaged percentage of red testa and breakage percentage of peanut kernel), physiological (germination) and biochemical (the contents of vitamin $E$ and aflatoxin $B_{1}$; acidity values, iodine values, peroxide values and fatty acid composition of peanut oil; solubility, emulsifying, foaming, water-holding capacity and oil-binding capacity of peanut protein) properties of peanut kernel were determined under different drying conditions (solar radiation, $35^{\circ} \mathrm{C}, 40^{\circ} \mathrm{C}, 45^{\circ} \mathrm{C}, 50^{\circ} \mathrm{C}, 55^{\circ} \mathrm{C}, 60^{\circ} \mathrm{C}$ ). The results showed that hot air temperatures had obvious influences on peanut qualities. The damaged percentage of red testa and breakage percentage of peanut kernel increased remarkably when the drying temperatures were above $45^{\circ} \mathrm{C}$. Meanwhile, when drying temperatures were more than $45^{\circ} \mathrm{C}$, the acid value and peroxide value of the extracted oil increased significantly. Furthermore, some properties exhibited prominent changes when the temperatures were higher than $50^{\circ} \mathrm{C}$, such as hardness, brittleness, germination percentage, and the Vitamin $E$ content of peanut kernel. In addition, the research results revealed that hot air can increase hydrophobicity of peanut protein and affect the functional properties of peanut protein. Therefore, it could be concluded that peanut should be dried by hot air below $45^{\circ} \mathrm{C}$ for quality maintenance. It also provided reference to choose suitable drying temperatures based on the final use of peanut.
\end{abstract}

Key words: peanut, hot air drying, drying temperatures, qualities

\section{Introduction}

Peanut is a widespread industrial oil crop, mainly cultivated in tropical and subtropical regions. Peanut food, such as peanut oil, peanut protein products, roasted peanut, fried peanut, peanut butter, and peanut confections, is widely used due to its high nutritional value ${ }^{1,2)}$. The oil content of peanut is as high as $45 \%$ to $50 \%$. And the peanut oil contains mostly monounsaturated and polyunsaturated fats, which are beneficial to human cardiovascular systems and can reduce hyperlipidemia and harmful cholesterol effectively ${ }^{3,4)}$. Peanut also contains a good source of protein, different vitamins and essential trace minerals ${ }^{5)}$.

After harvest, the moisture content of the peanut was very high, ranging from $30 \%$ to $55 \%$ on wet basis (w. b.). Peanut must be dried in time to ensure its safe storage and usage. If peanut was not dried to moisture content lower than $10 \%$ w. b. ${ }^{6,7)}$, it was susceptible to mold development and toxin production ${ }^{8)}$.

The peanut drying process can be performed based on many drying methods, such as solar radiation, hot air drying, microwave and radio frequency heating etc. ${ }^{9)}$. But the most commonly used methods were solar radiation and hot air drying ${ }^{9)}$. Drying by sun usually took a long time and was affected by weather. Hot air drying process can be performed by traditional bin dryers or semitrailers with heated air passing through the bed of peanuts ${ }^{10)}$. Studies on peanut drying by hot air mainly focused on drying parameters ${ }^{7)}$, the uniformity of peanut drying ${ }^{11)}$, the effective diffusion coefficient and the main thermodynamic proper$\operatorname{ties}^{12)}$, the mathematical model of thin layer drying ${ }^{12,13)}$, the non-isothermal drying models ${ }^{14)}$.

In addition to the above researches on peanut drying, there were also some studies on the quality of raw peanut

*Correspondence to: Chenling Qu, Dianxuan Wang, No. 100 of Lianhua Street, Zhengzhou City, Henan Province, People's Republic of CHINA

E-mail: quchenling82@163.com (CQ), wangdianxuan62@126.com (DW)

Accepted January 29, 2020 (received for review September 30, 2019)

Journal of Oleo Science ISSN 1345-8957 print / ISSN 1347-3352 online

http://www.jstage.jst.go.jp/browse/jos/ http://mc.manusriptcentral.com/jjocs 
and peanut products. Juhaimi et al. investigated the effects of storage and oven roasting on peanut qualities, such as oil yield, peroxide value, acidity, protein content and tocopherol content etc.. Idrus ${ }^{15)}$ and $\mathrm{Hu}^{16)}$ et al. reported that different peanut oil extraction methods induced different oil extraction ratio and oxidation quality changes. Moreover, the peanut protein isolate (PPI) was also discussed in literatures ${ }^{17-19)}$. The factors, e.g. $\mathrm{pH}$, ionic strength, temperature, growth environment and grain variety, can introduce significant changes in composition, structure and functionality of $\mathrm{PPI}^{20)}$. The influences of different dried methods (spray-dried PPI and freeze-dried PPI) and high pressure treatment on the physicochemical and functional properties of PPI were also investigated ${ }^{21,22)}$.

However, even after decades of investigating peanut drying and peanut quality, the effect of hot air drying temperatures on the degree of changes of peanut qualities had not yet been entirely clarified. Araujo ${ }^{23,24}$ focused on physical properties of peanut after drying at $40^{\circ} \mathrm{C}$, including bulk density, true density, intergranular porosity, thousand grain weight, sphericity, circularity, projected area, surface area and surface/volume ratio. And there were few studies on the effects of drying temperatures on the quality of peanut used as sources of seed, oil and protein. Therefore, this paper aimed to investigate these quality characteristics of peanut under different drying temperatures and provide a reference for peanut drying.

\section{Materials and Methods}

\subsection{Materials}

Samples of wet peanut Tianfu No. 3 were harvested in Weihui County, Henan Province, China.

\subsection{Peanut drying}

Hot air drying. A custom-designed heating system was applied for the drying process (shown in Fig. 1). During the process, air was heated (air temperature can be controlled by heating power) and conveyed into the air distribution chamber. Then the hot air was delivered to the drying chamber through orifice plate to dry the wet peanut. Approximately $30 \mathrm{~kg}$ wet peanut was placed in the drying chamber and dried at different temperatures $(35,40,45$, 50,55 and $\left.60^{\circ} \mathrm{C}\right)$ and relative humidities $(19.7,18.8,17.0$, $17.0,17.0$ and $8.0 \mathrm{RH} \%$ ) with volumetric flow rate $565 \mathrm{~m}^{3}$. $\mathrm{h}^{-1}$. The drying aeration was stopped when the moisture content of peanut reduced below $10 \%$. The terminal moisture contents of the peanut dried at 35, 40, 45, 50, 55 and $60{ }^{\circ} \mathrm{C}$ were $10.0 \%, 9.8 \%, 9.7 \%, 9.9 \%, 9.8 \%$ and $9.0 \%$ respectively. After drying, the dried peanuts were cooled to room temperature and dehulled by a dehusking machine (Henan Yuexin Industrial Co., Ltd., China, 2.2 kW). $500 \mathrm{~g}$ dehulled peanut was sampled for the quality analysis.

Solar radiation. Wet peanuts (initial moisture content $22.1 \pm 0.9 \%)$ were spread on the ground and dried by the sun. The drying time was between 9 a.m. to 17 p.m. in the daytime (temperature was $14-24^{\circ} \mathrm{C}$, average relative humidity was 50-60 RH\%). In the night (17 p.m. to 9 a.m.), the peanuts were piled up and covered to prevent the moisture



Fig. 1 Drying system.

1. Fan, 2. Aeration duct, 3. Electrical heating apparatus, 4. Flowmeter, 5. Air distribution chamber, 6. Temperature and humidity sensor, 7. Orifice plate, 8. Drying chamber, 9. Wet peanuts 
absorption. After 3 days' drying, the moisture content of peanuts was $9.50 \%$. Then the peanuts were dehulled by the dehusking machine. The obtained dried peanuts were dehulled and used for quality determination (control group).

\subsection{Moisture content determination ( $\%$ wet basis)}

The moisture content of peanut was determined according to the American Society of Agricultural and Biological Engineers (ASABE) method S410.2 at $130^{\circ} \mathrm{C}$ for $6 \mathrm{~h}^{25,26)}$.

\subsection{Physical characteristics}

\subsubsection{Texture determination}

The TA.XT plus texture analyzer (Stable Micro systems, TA.XT plus, UK) with a A/ECB blade was used. The peanut kernel was put on the platform of texture analyzer perpendicular to the blade. The parameters of the texture analyzer were as follows: trigger force, $5.0 \mathrm{~g}$, pretest and blade movement speed, $1 \mathrm{~mm} \cdot \mathrm{s}^{-1}$; post-test speed, $10 \mathrm{~mm} \cdot \mathrm{s}^{-1}$; and strain, 50\%. The data acquisition rate was set at 200 points per second. Hardness (g) was the maximum amount of force required to fracture the kernel, which was recorded as the height of the maximum peak. Brittleness (g)was the amount of force needed on the first fracture of the kernel, which was recognized as the height of the first peak.

2.4.2 Damaged percentage of red testa(DP) and Breakage percentage (BP) of peanut kernel

After drying, the peanuts were cooled to room temperature and were dehulled using the dehusking machine. 200 $\mathrm{g}$ dried peanuts were taken to test the DP and BP of peanut kernel. DP was defined as more than $20 \%$ of the testa or skin removed during dehulling. BP was considered as the two cotyledons separated or fragmented. Each test at various drying temperatures was repeated five times. DP was expressed by the percentage of the weight of red testa damaged peanut kernel to the total weight. And BP was shown by the percentage of the weight of breakage peanut kernels to the total weight.

\subsection{Germination tests}

According to Chinese National Standard GB/T 55202011, samples of 50 peanut kernels were sowed in wet sand and placed at $25^{\circ} \mathrm{C}$ in a climate incubator. After 10 days, the number of spouted peanuts was counted. The germination percentage was defined as the number of successfully germinated kernels out of the total number of the peanut kernels.

\subsection{Vitamin $\mathrm{E}(\mathrm{VE})$ determination}

The contents of VE in the peanut kernel were determined by VE test kits (Nanjing Jiangcheng Bioengineering Institute, China) according to the manufacturer's protocol. This method was based on the reaction of VE with phenan- throline to form a pink complex, which can be read at 533 nm absorbance.

\subsection{Determination of aflatoxin $\mathrm{B}_{1}\left(\mathrm{AFB}_{1}\right)$ content}

The contents of $\mathrm{AFB}_{1}$ in peanut kernels were determined by ELISA test kits ${ }^{27)}$ (quantitative kit for $\mathrm{AFB}_{1}$, Huaan Magnech Bio-Tech Co., Ltd., China) as the manufacturer's instructions. Indirect competition ELISA method was applied in this kit. Briefly, the aflatoxin $\mathrm{B}_{1}$ antigen was precoated on the micro-wells of the reaction plate. The precoated aflatoxin $\mathrm{B}_{1}$ and aflatoxin $\mathrm{B}_{1}$ from the sample would bind with the primary antibodies of aflatoxin $\mathrm{B}_{1}$ competitively. The quantity of antibodies captured by the pre-coated aflatoxin $B_{1}$ depended on the concentration of the aflatoxin $B_{1}$ in the sample. The larger the concentration, the less the primary antibodies binding to the pre-coated aflatoxin $\mathrm{B}_{1}$. Then the complexes of the antibodies and precoated aflatoxin $\mathrm{B}_{1}$ antigen were bond with horseradish peroxidase (HRP) -labled secondary antibodies. Subsequently, substrate (3,3',5,5'-Tetramethylbenzidine, TMB) was added and $\mathrm{OD}_{450}$ was measured. The absorbance was negatively correlated with the aflatoxin $\mathrm{B}_{1}$ concentrations of the samples.

\subsection{Peanut oil analysis}

\subsubsection{Peanut oil extraction}

The oil contents in dried peanuts were determined according to Chinese National Standard GB/T 14488.1-2008. The dried peanut kernels were cut into thin slices (about 1 mm thickness) with DQ-101 slicer (Zhengzhou Gashili Machinery CO., LTD), then the peanut thin slices were ground into granules by FZ102 miniature plant sample pulveriser (Beijing Ever Bright Medical Treatment Instrument Co., Ltd., China) and passed through $3 \mathrm{~mm}$ sieve pores. In order to avoid the heating influence on the peanut quality during the slicing and smashing process, several minutes' pause existed between each operation. Peanut oil was extracted from peanut kernel granules with petroleum ether (boiling range $30-60^{\circ} \mathrm{C}$, Tianjin Tianli Chemical Reagent Co.) by Soxhlet extraction for $8 \mathrm{~h}$. The mass fraction of the obtained extract in the original sample was the oil content.

The peanut oil was extracted by the above extraction method by petroleum ether. Then the solvent was evaporated using a rotary vacuum evaporator (RE-2000A, China) with a water bath temperature not higher than $30^{\circ} \mathrm{C}$. The extracted oil was immediately used for chemical analysis, including acidity values (AV), iodine values (IV), peroxide values (PV) and fatty acid composition (FAC).

2.8.2 Chemical analysis

Acidity values, iodine values and peroxide values were tested based on Chinese National Standard GB 5009.2292016, GB 5009.227-2016 and GB/T 5532-2008, respectively. Fatty acid composition of peanut oil was measured according to Chinese National Standard GB 5009.168-2016 using 
gas chromatography (7890 B, Agilent Technologies, USA) equipped with a capillary column $(100 \mathrm{~m} \times 0.25 \mathrm{~mm} \times 0.20$ $\mu \mathrm{m})$ and a flame ionization detector.

\subsection{Peanut protein analysis}

2.9.1 Preparation of peanut protein isolate(PPI)

PPI was prepared using isoelectric precipitation, as described by Gong et $a l .{ }^{21)}$ with some modification. The defatted sample was mixed with water in the ratio of $1 / 10(\mathrm{w} / \mathrm{v})$. And the $\mathrm{pH}$ of the mixture was adjusted to 9 with $1 \mathrm{M}$ sodium hydroxide $(\mathrm{NaOH}$, Tianjin Kemiou Chemical Reagent Co., Ltd.) solution to dissolve the peanut protein. After stirring for $1 \mathrm{~h}$, the mixture was centrifuged to obtain the supernatant as peanut protein solution. The supernatant was adjusted with $1 \mathrm{M}$ hydrochloric acid ( $\mathrm{HCl}$, Luoyang Haohua Chemical Reagent Co., Ltd) to $\mathrm{pH} 4.5$ to precipitate the peanut protein. Then the suspension was centrifuged and the precipitate was dried by a freeze drier (LGJ-10C, Four-Ring Science Instrument Plant Beijing CO., LTD, China).

2.9.2 Determination of the functional properties of peanut protein

The protein solubility in water, emulsifying and foaming properties were calculated at $\mathrm{pH} 9$ using the method of Jamdar et al. ${ }^{28)}$. Water-holding capacity (WHC) and oilbinding capacity (OBC) of samples were determined as described by He et $a l .{ }^{22)}$.

\subsection{Data analysis}

Data processing was used by Origin (version 9.0) and statistical analysis was performed by SPSS (version 21.0). One-way analysis of variance (ANOVA) was employed to determine significant differences and Duncan's test was used to perform multiple comparisons between means. Two-sided in which $p<0.05$ were considered to be significant.

\section{Results and Discussion}

3.1 Moisture content (M.C., \% dry weight)

As a control, the moisture content of wet peanuts decreased from $22.1 \%$ to $10.0 \%$ in 3 days by solar radiation. The drying curves of wet peanuts at different drying temperatures were illustrated in Fig. 2, where the increase of the hot air temperature considerably reduced the drying time. At the drying temperatures of $35,40,45,50,55$ and $60^{\circ} \mathrm{C}$, the initial moisture contents were $22.9 \%, 19.5 \%$, $18.6 \%, 17.7 \%, 20.4 \%$ and $18.8 \%$, the final moisture contents were $10.0 \%, 9.8 \%, 9.7 \%, 9.9 \%, 9.8 \%$ and $9.0 \%$, and the drying time were $18.0 \mathrm{~h}, 13.5 \mathrm{~h}, 10.0 \mathrm{~h}, 8.0 \mathrm{~h}, 5.5 \mathrm{~h}$ and $4.7 \mathrm{~h}$, respectively. The rise of the drying temperature increased the difference between the partial steam pressure of the drying air and the peanut during the water removal,

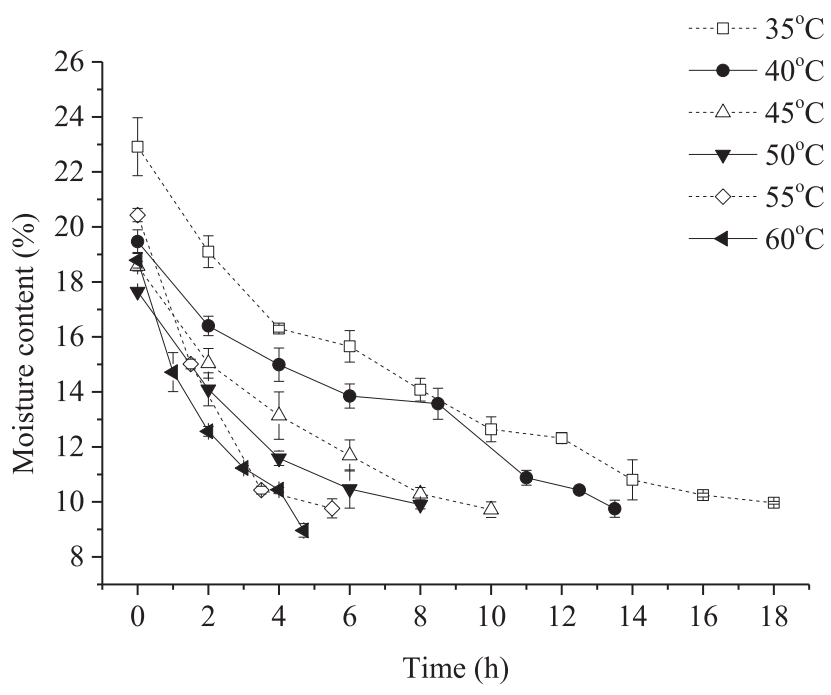

Fig. 2 Drying curves of wet peanuts at different drying temperatures.

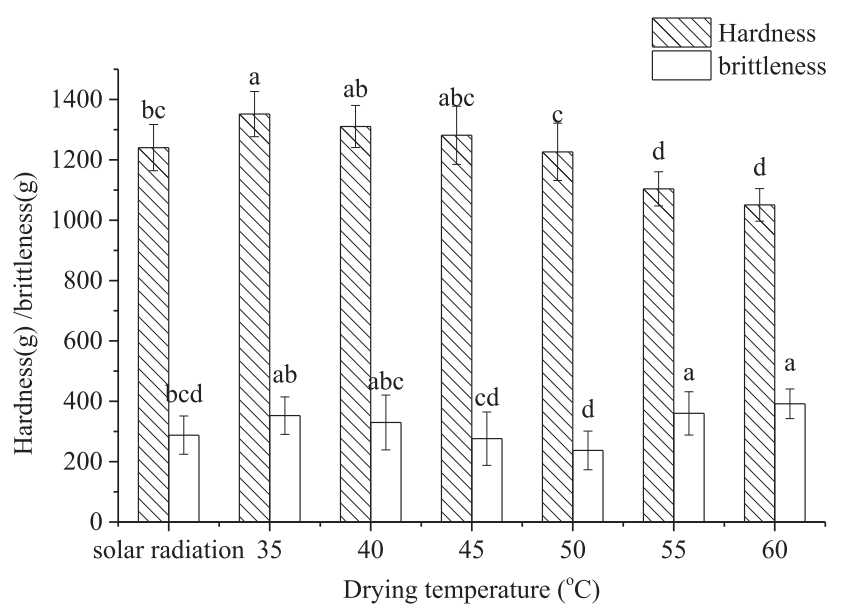

Fig. 3 Hardness and brittleness of peanut kernels after drying at different drying temperatures.

All values were expressed as means \pm standard error of decuplicate experiments. Different letters on the bars indicate significant difference $(p<$ $0.05)$.

which led to higher drying rate and reduced drying time ${ }^{12}$. Therefore, compared with solar radiation, hot air drying could improve drying efficiency effectively.

\subsection{Physical, physiological, and chemical characteristics}

Texture determination. Texture characteristics, hardness and brittleness, of dehulled peanut dried at different temperatures were shown in Fig. 3. It can be seen from Fig. 3 that there was no significant change in hardness and brittleness when the drying temperatures were equal to or less than $50^{\circ} \mathrm{C}(p<0.05)$. When the drying temperatures were higher than $50^{\circ} \mathrm{C}$, the hardness exhibited a downward trend, but the brittleness showed an upward trend. The 


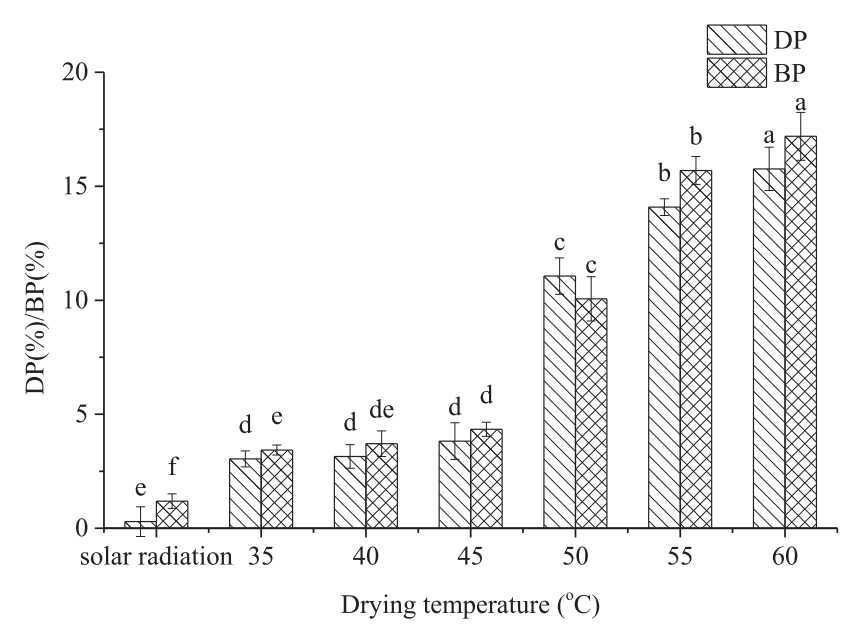

Fig. 4 Damaged percentage of red testa(DP) and breakage percentage of peanut kernel(BP) after being shelled after drying at different drying temperatures.

All values were expressed as means \pm standard error of quintuplicate experiments. Different letters on the bars indicate significant difference $(p$ $<0.05)$.

results illustrated that air temperature influenced the texture of peanut kernel. It may be due to that hot air with higher temperature could accelerate the heat and mass transfer rates, which led to the microstructure disrupted ${ }^{29,30)}$. Moreover, higher temperature may affect the structures and the intermolecular forces of protein, starch and fat in the peanut kernel, which resulted in the texture changes of peanut kernels.

Damaged percentage of red testa (DP) and Breakage percentage (BP). Figure 4 displayed the DPs and BPs of peanut kernels under different drying temperatures. The $\mathrm{DP}$ and BP of peanut kernels with solar radiation were $0.29 \%$ and $1.19 \%$, respectively. And hot air drying can lead to significant increases of the DPs and BPs of dried peanut kernels $(p<0.05)$. When the hot air temperatures were $35^{\circ} \mathrm{C}, 40^{\circ} \mathrm{C}$ and $45^{\circ} \mathrm{C}$, DPs and BPs rose slightly, and all were less than $5 \%$. The DP increased to $11.06 \%, 14.08 \%$, $15.76 \%$, and BP ascended to $10.06 \%, 15.69 \%$ and $17.19 \%$ respectively as the drying temperatures were $50^{\circ} \mathrm{C}, 55^{\circ} \mathrm{C}$ and $60^{\circ} \mathrm{C}$. When the hot air temperatures were higher than or equal to $50^{\circ} \mathrm{C}$, mechanical shelling would seriously affect the integrity of peanut kernels. This phenomenon may be also owing to the higher heat and mass transfer rates in the peanut kernel at higher drying temperatures, which caused the disruption of the kernel microstructure. Therefore, drying temperature can have remarkable impacts on the appearance quality and commercial value of peanuts. The quality of peanut kernel with higher DP and BP would deteriorate more easily during storage because the broken kernels lost the protection of red testa and could be oxi-

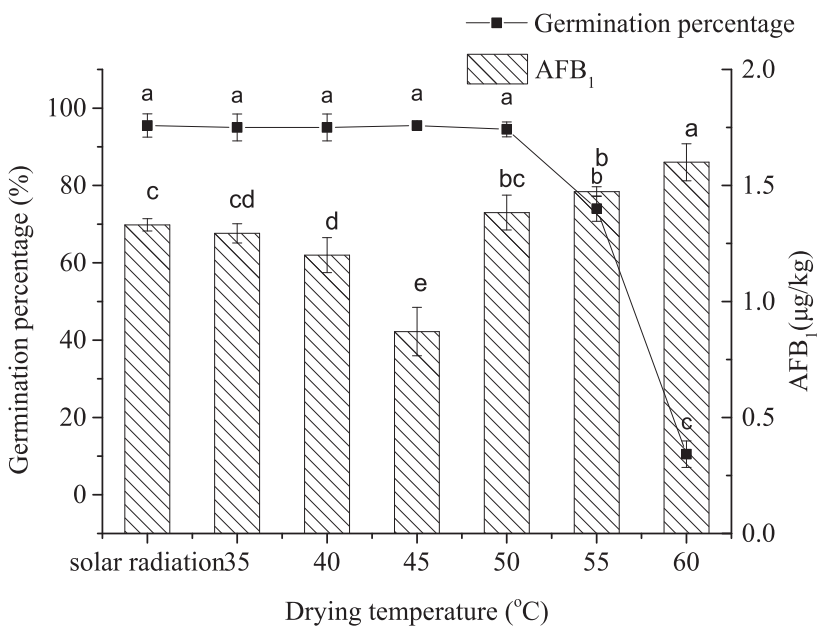

Fig. 5 Germination percentage and aflatoxin $\mathrm{B}_{1}$ contents of peanut kernel after drying at different drying temperatures.

All values were expressed as means \pm standard error of quadruplicate experiments. Different letters on the bars indicate significant difference $(p$ $<0.05)$.

dized more easily than the sound kernels.

Germination. Germination was an important indicator of peanut seed vigor. Seed viability can be affected by several factors such as, moisture content, cracks in the seed coat, fungal attacks, mechanical injuries in the seed harvesting or processing operations ${ }^{31)}$. It can be seen from Fig. 5 that the germination percentage of peanut seeds were significantly affected by drying temperatures above $55^{\circ} \mathrm{C}(p<$ $0.05)$. The germination percentage of peanut kernel were not influenced by solar radiation and by hot air at $35^{\circ} \mathrm{C}$, $40^{\circ} \mathrm{C}, 45^{\circ} \mathrm{C}$ and $50^{\circ} \mathrm{C}$, which were $96 \%, 95 \%, 95 \%, 96 \%$ and $95 \%$, respectively. However, as compared to the control, the germination percentage dropped to $74 \%$ and $11 \%$ correspondingly when the hot air temperatures were $55^{\circ} \mathrm{C}$ and $60^{\circ} \mathrm{C}$. It was because that the higher drying temperature denatured the enzymes related to seed germination, thus reducing the germination rate of peanut seeds.

The contamination of aflatoxin $\mathrm{B}_{1}\left(\mathrm{AFB}_{1}\right)$. Peanut were susceptibly contaminated by $\mathrm{AFB}_{1}$ during harvest, storage, drying and processing. And $\mathrm{AFB}_{1}$ was toxic with strong carcinogenic properties $^{32}$. The optimum temperature and water activity for aflatoxin production were $33^{\circ} \mathrm{C}$ and $0.99^{33)}$. Therefore, levels of $\mathrm{AFB}_{1}$ contamination were also monitored after the drying and were presented in Fig. 5. The contents of $\mathrm{AFB}_{1}$ of the dried peanut kernel samples with different drying temperatures were all below $2.00 \mu \mathrm{g}$. $\mathrm{kg}^{-1}$. The level detected were much lower than $20 \mu \mathrm{g} \cdot \mathrm{kg}^{-1}$, which was the limit the $\mathrm{AFB}_{1}$ quantity according to the Chinese National Standard GB 2761-2017.

Vitamin E(VE) contents in the peanut kernel. The antioxidant activity in peanut kernel was attributed to VE 


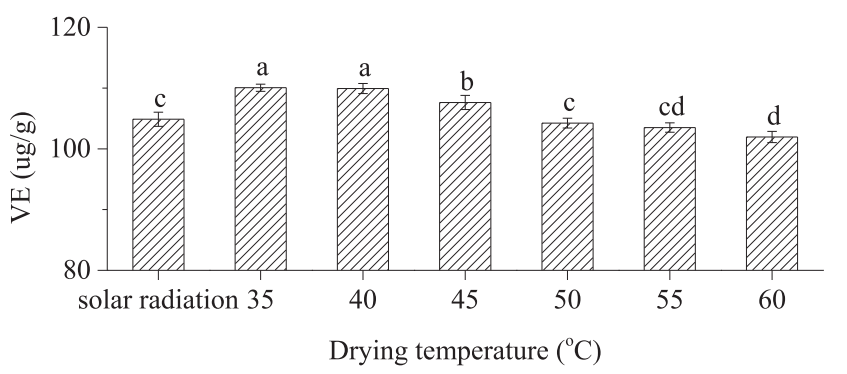

Fig. 6 VE content after drying at different drying temperatures.

All values were expressed as means \pm standard error of triplicate experiments. Different letters on the bars indicate significant difference $(p<0.05)$.

content ${ }^{34)}$. The effect of solar radiation and hot air drying on the VE content in peanut kernel was shown in Fig. 6. It can be seen from Fig. 6 that the VE content of peanut dried by solar radiation was $104.9 \pm 1.2 \mu \mathrm{g} \cdot \mathrm{g}^{-1}$, and that dried by hot air at $35^{\circ} \mathrm{C}, 40^{\circ} \mathrm{C}, 45^{\circ} \mathrm{C}, 50^{\circ} \mathrm{C}, 55^{\circ} \mathrm{C}, 60^{\circ} \mathrm{C}$ were $110.1 \pm 0.6 \mu \mathrm{g} \cdot \mathrm{g}^{-1}, 109.9 \pm 0.8 \mu \mathrm{g} \cdot \mathrm{g}^{-1}, 107.6 \pm 1.2 \mu \mathrm{g} \cdot \mathrm{g}^{-1}$, $104.2 \pm 0.8 \mu \mathrm{g} \cdot \mathrm{g}^{-1}, 103.5 \pm 0.8 \mu \mathrm{g} \cdot \mathrm{g}^{-1}$ and $102.0 \pm 0.9 \mu \mathrm{g} \cdot \mathrm{g}^{-1}$, respectively. From the statistical analysis, drying at $35^{\circ} \mathrm{C}$, $40^{\circ} \mathrm{C}$ and $45^{\circ} \mathrm{C}$ were significantly $(p<0.05)$ beneficial to protect the antioxidant activity of peanut kernel than other drying conditions. Hence, exposure to the sun for a long time and higher temperatures would damage the antioxidant activity of peanut kernel to some extent. Martín et $a l .{ }^{40)}$ also demonstrated the effectiveness of oxygen isolation and low temperature environment in protecting the quality of tocopherols.

\subsection{Chemical analysis of peanut oil extracted from dried peanut kernels}

3.3.1 Oil content, Acid value (AV), Iodine value(IV) and Peroxide value (PV)

Oil content is one of the key indexes to evaluate the production efficiency of oil from oilseeds ${ }^{35}$. As can be seen from Table 1, the contents of the peanut oil extracted from dried peanut kernels obtained by solar radiation and hot air were between $46.67 \%$ and $47.24 \%$, which showed no significant difference $(p<0.05)$.

The acid value $(\mathrm{AV})$ represented the level of free fatty acids in oil, which was an indicator of oil rancidity ${ }^{36}$. The variations of the $\mathrm{AV}$ of peanut oil were exhibited in Table 1. The results indicated that drying temperatures higher than $50^{\circ} \mathrm{C}$ had a negative effect on the $\mathrm{AV}$ of peanut oil compared to the control and low temperature drying groups. The reason was that the fat hydrolysis reaction, which made the decomposition of glycerides, developed rancidity, led to the formation of free fatty acids in peanut oil, was closely related to temperature and can be accelerated at higher temperatures ${ }^{15}$. Although the AV values of peanut were affected by drying temperature, the AV values after drying at higher temperatures were still far below the limit in the Chinese National Standard GB/T 1534-2017, which allowed for the presence of $\mathrm{AV}$ up to $2.0 \mathrm{mg} \mathrm{NaOH} \mathrm{g}{ }^{-1}$ in leaching peanut oil.

Iodine value (IV) is an indicator which showed the unsaturation degree of the peanut oil, a greater degree of unsaturation was accompanied by a higher $\mathrm{IV}^{37}$. It can be seen from Table 1 that drying temperature did not cause significant changes in IV $(p<0.05)$, which were at the range of $94.2-96.9 \mathrm{~g} \cdot 100 \mathrm{~g}^{-1}$ and not significantly different from the control $97.8 \pm 1.4 \mathrm{~g} \cdot 100 \mathrm{~g}^{-1}(p<0.05)$. Hence, peanut drying using hot air within $60^{\circ} \mathrm{C}$ did not cause unacceptable results in terms of unsaturated fatty acids of peanut oil.

Peroxide value (PV) measured the quantity of peroxides in the oil, which served as an indicator index of the primary oxidation product formation ${ }^{16)}$. It was widely employed as a measure of oil oxidative rancidity ${ }^{38)}$. As illustrated in Table 1 , the drying temperatures displayed a little influence on $\mathrm{PV}$ of peanut oil obtained after hot air drying above $50^{\circ} \mathrm{C}$. The above results showed that higher drying temperature could produce more peroxides and increase the oxidation rate of peanut oils. It was because more peroxide were produced at higher drying temperature, which led to

Table 1 Effects of drying temperature on chemical properties of peanut oil extracted from peanut kernel after drying at different temperatures.

\begin{tabular}{|c|c|c|c|c|c|c|c|}
\hline $\begin{array}{l}\text { Drying temperature } \\
\left({ }^{\circ} \mathrm{C}\right)\end{array}$ & solar radiation & 35 & 40 & 45 & 50 & 55 & 60 \\
\hline $\begin{array}{l}\text { Oil content } \\
(\%)\end{array}$ & $47.24 \pm 0.61^{\mathrm{a}}$ & $46.74 \pm 0.10^{\mathrm{a}}$ & $47.06 \pm 0.40^{\mathrm{a}}$ & $46.71 \pm 0.16^{\mathrm{a}}$ & $46.67 \pm 0.14^{\mathrm{a}}$ & $46.87 \pm 0.12^{\mathrm{a}}$ & $46.68 \pm 0.18^{\mathrm{a}}$ \\
\hline $\begin{array}{c}\text { Acid value } \\
\left(\mathrm{mg} \mathrm{NaOH} \mathrm{g}^{-1} \text { oil }\right)\end{array}$ & $0.087 \pm 0.004^{\mathrm{b}}$ & $0.090 \pm 0.003^{b}$ & $0.085 \pm 0.004^{b}$ & $0.093 \pm 0.003^{b}$ & $0.124 \pm 0.002^{\mathrm{a}}$ & $0.118 \pm 0.004^{\mathrm{a}}$ & $0.122 \pm 0.002^{2}$ \\
\hline $\begin{array}{l}\text { Iodine number } \\
\left(\mathrm{g} \mathrm{I}_{2} 100 \mathrm{~g}^{-1} \text { oil }\right)\end{array}$ & $97.8 \pm 1.4^{\mathrm{a}}$ & $94.3 \pm 1.7^{\mathrm{a}}$ & $95.9 \pm 1.5^{\mathrm{a}}$ & $94.2 \pm 2.4^{\mathrm{a}}$ & $96.1 \pm 0.8^{\mathrm{a}}$ & $96.9 \pm 1.5^{\mathrm{a}}$ & $96.7 \pm 1.8^{\mathrm{a}}$ \\
\hline $\begin{array}{c}\text { Peroxide value } \\
\left(\mathrm{mmol} \mathrm{O}_{2} \mathrm{~kg}^{-1} \mathrm{Oil}\right)\end{array}$ & $0.24 \pm 0.02^{\mathrm{b}}$ & $0.24 \pm 0.02^{\mathrm{b}}$ & $0.24 \pm 0.01^{\mathrm{b}}$ & $0.24 \pm 0.01^{\mathrm{ab}}$ & $0.26 \pm 0.01^{\mathrm{ab}}$ & $0.27 \pm 0.02^{\mathrm{a}}$ & $0.27 \pm 0.02^{\mathrm{a}}$ \\
\hline
\end{tabular}

Data were expressed as means \pm standard deviations. Different superscript letters in the same row show a significant difference $(p<0.05)$. 
Table 2 Fatty acid composition of peanut oil extracted from peanut kernel after drying at different temperatures.

\begin{tabular}{|c|c|c|c|c|c|c|c|}
\hline \multirow{2}{*}{$\begin{array}{c}\text { fatty acids } \\
\text { composition (\%) }\end{array}$} & \multicolumn{7}{|c|}{ Drying temperature $\left({ }^{\circ} \mathrm{C}\right)$} \\
\hline & solar radiation & 35 & 40 & 45 & 50 & 55 & 60 \\
\hline Palmitic acid C16:0 & $10.85 \pm 0.47^{\mathrm{a}}$ & $11.27 \pm 0.05^{\mathrm{a}}$ & $11.16 \pm 0.06^{\mathrm{a}}$ & $11.17 \pm 0.03^{\mathrm{a}}$ & $11.02 \pm 0.01^{\mathrm{a}}$ & $11.20 \pm 0.04^{\mathrm{a}}$ & $11.18 \pm 0.05^{\mathrm{a}}$ \\
\hline Stearic acid C18:0 & $2.48 \pm 0.22^{\mathrm{a}}$ & $2.77 \pm 0.31^{\mathrm{a}}$ & $2.56 \pm 0.01^{\mathrm{a}}$ & $2.60 \pm 0.01^{\mathrm{a}}$ & $2.60 \pm 0.01^{\mathrm{a}}$ & $2.57 \pm 0.01^{\mathrm{a}}$ & $2.47 \pm 0.01^{\mathrm{a}}$ \\
\hline Oleic acid C18:1-9 & $44.08 \pm 0.69^{\mathrm{a}}$ & $43.96 \pm 0.06^{\mathrm{a}}$ & $43.90 \pm 0.02^{\mathrm{a}}$ & $43.99 \pm 0.01^{\mathrm{a}}$ & $44.22 \pm 0.02^{\mathrm{a}}$ & $43.77 \pm 0.01^{\mathrm{a}}$ & $43.74 \pm 0.06^{\mathrm{a}}$ \\
\hline $\begin{array}{l}\text { Linoleic acid } \\
\text { C18:2-6 }\end{array}$ & $35.71 \pm 0.42^{\mathrm{a}}$ & $34.35 \pm 1.21^{\mathrm{a}}$ & $35.15 \pm 0.01^{\mathrm{a}}$ & $35.02 \pm 0.01^{\mathrm{a}}$ & $35.06 \pm 0.01^{\mathrm{a}}$ & $35.23 \pm 0.05^{\mathrm{a}}$ & $35.29 \pm 0.01^{\mathrm{a}}$ \\
\hline $\begin{array}{l}\text { Arachidic acid } \\
\text { c20:0 }\end{array}$ & $1.28 \pm 0.13^{\mathrm{a}}$ & $1.48 \pm 0.22^{\mathrm{a}}$ & $1.37 \pm 0.01^{\mathrm{a}}$ & $1.38 \pm 0.01^{\mathrm{a}}$ & $1.37 \pm 0.01^{\mathrm{a}}$ & $1.37 \pm 0.01^{\mathrm{a}}$ & $1.35 \pm 0.01^{\mathrm{a}}$ \\
\hline $\begin{array}{l}\text { Gadoleic acid } \\
\text { C20:1-9 }\end{array}$ & $1.09 \pm 0.05^{\mathrm{b}}$ & $1.12 \pm 0.02^{\mathrm{a}}$ & $1.13 \pm 0.01^{\mathrm{ab}}$ & $1.18 \pm 0.05^{\mathrm{ab}}$ & $1.15 \pm 0.01^{\mathrm{ab}}$ & $1.17 \pm 0.02^{\mathrm{ab}}$ & $1.2 \pm 0.01^{\mathrm{ab}}$ \\
\hline Behenic acid C22:0 & $2.83 \pm 0.07^{\mathrm{a}}$ & $2.97 \pm 0.23^{\mathrm{a}}$ & $2.9 \pm 0.02^{\mathrm{a}}$ & $2.93 \pm 0.02^{\mathrm{a}}$ & $2.87 \pm 0.01^{\mathrm{a}}$ & $2.94 \pm 0.03^{\mathrm{a}}$ & $2.99 \pm 0.01^{\mathrm{a}}$ \\
\hline $\begin{array}{l}\text { Lignoceric acid } \\
\text { C24:0 }\end{array}$ & $1.4 \pm 0.18^{\mathrm{a}}$ & $1.71 \pm 0.31^{\mathrm{a}}$ & $1.55 \pm 0.03^{\mathrm{a}}$ & $1.55 \pm 0.01^{\mathrm{a}}$ & $1.52 \pm 0.01^{\mathrm{a}}$ & $1.56 \pm 0.01^{\mathrm{a}}$ & $1.59 \pm 0.01^{\mathrm{a}}$ \\
\hline$\sum \mathrm{SFA}$ & $19.17 \pm 0.60^{\mathrm{a}}$ & $19.16 \pm 0.36^{\mathrm{a}}$ & $19.54 \pm 0.01^{\mathrm{a}}$ & $19.62 \pm 0.06^{\mathrm{a}}$ & $19.38 \pm 0.01^{\mathrm{a}}$ & $19.63 \pm 0.03^{\mathrm{a}}$ & $19.57 \pm 0.04^{\mathrm{a}}$ \\
\hline$\sum \mathrm{UFA}$ & $80.83 \pm 0.60^{\mathrm{a}}$ & $80.84 \pm 0.36^{\mathrm{a}}$ & $80.46 \pm 0.01^{\mathrm{a}}$ & $80.38 \pm 0.06^{\mathrm{a}}$ & $80.62 \pm 0.01^{\mathrm{a}}$ & $80.37 \pm 0.03^{\mathrm{a}}$ & $80.43 \pm 0.04^{\mathrm{a}}$ \\
\hline
\end{tabular}

Data were expressed as means \pm standard deviations. Different superscript letters in the same row show a significant difference $(p<0.05)$. SFA saturated fatty acids, UFA unsaturated fatty acids.

higher PV values ${ }^{39)}$.

3.3.2 Fatty Acid Composition

Analysis of the fatty acid composition (FAC) was a useful tool for detecting classes of lipids which were involved in the oxidative changes ${ }^{40)}$. From Table 2, it can be seen that the major FAC in peanut oil were oleic acid (18:1-9), linoleic $\operatorname{acid}(18: 2-6)$ and palmitic acid (16:0), whose ratio were ranged between $43.74 \%$ and $44.22 \%$, between $34.35 \%$ and $35.71 \%$, between $10.85 \%$ and $11.27 \%$, respectively. A large proportion (about $80 \%$ ) of unsaturated fatty acids, including monounsaturated fatty acids and polyunsaturated fatty acids, was detected in peanut oil. And the total amounts of unsaturated fatty acids in peanut did not undergo obvious oxidation deterioration $(p<0.05)$ in the process of hot air drying at $35-60^{\circ} \mathrm{C}$ for $5-18 \mathrm{~h}$ (Fig. 2). Abbas et $a l .{ }^{41)}$ reported that the FAC did not change with roasting in peanut oil at $170^{\circ} \mathrm{C}$ for $7.5 \mathrm{~min}$. Therefore, it can be concluded that drying temperature had no significant effect on FAC of peanut oil during the peanut drying process $(p<0.05)$.

\subsection{Functional properties of Peanut Protein Isolate (PPI)}

Protein solubility. Protein solubility was one of the most important physicochemical properties, which was closely related to the denaturation degree of protein ${ }^{17)}$. Protein solubility expressed as nitrogen solubility index (NSI). After hot air drying, NSI of peanut protein isolate(PPI) decreased significantly $(p<0.05)$ along with the increase of hot air temperature (Table 3 ), which was reduced to a minimum of $114.21 \pm 0.69 \mathrm{mg} \mathrm{N} \cdot 100 \mathrm{~g}^{-1}$ at $60^{\circ} \mathrm{C}(p<0.05)$ compared to the control $\left(142.33 \pm 0.58 \mathrm{mg} \mathrm{N} \cdot 100 \mathrm{~g}^{-1}\right)$. It implied that the hot air temperature had a negative influ- ence on the solubility of PPI. The decreasing solubility of PPI may be due to the structure denaturation of PPI caused by high temperature drying, which increased exposure of hydrophobic groups and reduced the protein-water interactions. These results corresponded with the studies of Ziegler et $a l .{ }^{42)}$ and Lee et $a l .{ }^{43)}$.

Foaming properties. The effects of drying temperature on foaming capacity (FC) and foaming stability (FS) of peanut protein isolate (PPI) were presented in Table 3. The FC and FS were all significantly influenced by drying temperatures $(p<0.05)$. The FC of PPI was increased to $18.00 \%, 20.33 \%, 16.83 \%, 17.50 \%, 19.25 \%$ and $20.75 \%$ as the drying temperatures increased from $35^{\circ} \mathrm{C}$ to $60^{\circ} \mathrm{C}$ in comparison with the control $13.45 \%$. In addition, the changes of FS of PPI showed a similar changing pattern. The FS increased overall, from $14.50 \%$ to $17.67 \%$ as drying temperature increased from $35^{\circ} \mathrm{C}$ to $60^{\circ} \mathrm{C}$. These data demonstrated that heat-induced denaturation of PPI would favor the forming of air-trapping film and stabilizing the foam ${ }^{44)}$.

Emulsifying properties. Emulsification activity index (EAI) represented the ability of a protein to promote emulsion formation. And emulsification stability (ES) indicated the ability of the emulsion to resist destabilizing variations $^{21)}$. Although there were some differences in values of EAI and ES at different drying temperatures, the changing trends of the EAI and ES with different drying temperatures was not obvious (Table 3). EAI varied between 59.80 \pm 0.44 and $65.51 \pm 0.87 \mathrm{~m}^{2} \cdot \mathrm{g}^{-1}$, and ES varied between $92.09 \pm 0.63$ and $98.50 \pm 0.94 \%$. Hence, drying temperatures below $60^{\circ} \mathrm{C}$ had only a little effect on emulsifying properties of peanut protein isolate. 


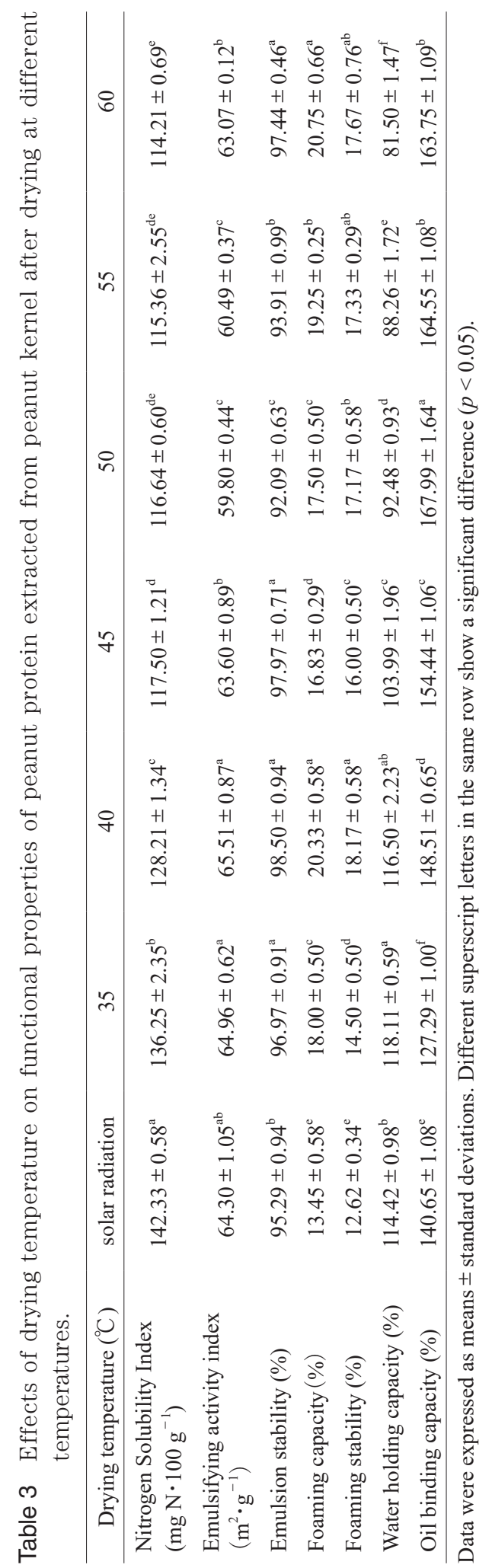

Water holding capacity (WHC) and oil binding capacity (OBC). WHC is used to determine the water remaining ability of proteins, and OBC expressed the oil binding ability of proteins ${ }^{45)}$. It was presented in Table 3 that WHC of peanut protein isolate (PPI) was significantly influenced by hot air temperatures $\left(45^{\circ} \mathrm{C}, 50^{\circ} \mathrm{C}, 55^{\circ} \mathrm{C}\right.$ and $60^{\circ} \mathrm{C} ; p<$ 0.05). And all the WHC of PPI obtained from peanut kernels dried by hot air showed significantly lower values than those in the control group $(p<0.05)$. The WHC values decreased as the drying temperatures increased. Nevertheless, OBC increased with the rise of drying temperature. The possible reason was that the increase of drying temperature caused the denaturation of PPI, which led to the exposure of hydrophobic groups ${ }^{44)}$. Increased PPI hydrophobicity resulted in increased WHC and decreased OBC.

\section{Conclusion}

Peanuts usually have high moisture content after harvest and must be dried to avoid mildew. Hot air drying was the most commonly used method for peanut drying. During the hot air drying process, the drying conditions, especially the drying temperature, would affect the qualities of peanuts. However, there were no relevant detailed reports at present. The results in this paper demonstrated that when drying temperatures were higher than $50^{\circ} \mathrm{C}$, peanut seed vigor dropped a lot, and vitamin $\mathrm{E}$ contents, brittleness and hardness also showed significant changes. When drying temperatures were higher than $45^{\circ} \mathrm{C}$, damaged percentage of red testa, breakage percentage, acid value and peroxide value changed significantly. As the air temperature increased, the functional properties of peanut protein isolate also exhibited significant changes. These data offered suitable peanut drying parameters for different uses of peanuts.

\section{Acknowledgements}

This work was supported by grants from China Agriculture Research System(CARS-13) and Key scientific research projects in universities of Henan Province (20B550002).

\section{References}

1) Wang, Q.; Liu, H.Z.; Shi, A.M.; Hu, H.; Liu, L.; Wang, L.; $\mathrm{Yu}, \mathrm{H} . \mathrm{W}$. Review on the processing characteristics of cereals and oilseeds and their processing suitability evaluation technology. J. Integr. Agr. 16, 2886-2897 (2017).

2) Giuffre, A.M.; Tellah, S.; Capocasale, M.; Zappia, C.; 
Latati, M.; Badiani, M.; Ounane, S.M. Seed oil from ten algerian peanut land races for edible use and biodiesel production. J. Oleo Sci. 65, 9-20(2016).

3) Shasidhar, Y.; Vishwakarma, M.K.; Pandey, M.K.; Janila, P.; Variath, M.T.; Manohar, S.S.; Nigam, S.N.; Guo, B.; Varshney, R.K. Molecular mapping of oil content and fatty acids using dense genetic maps in groundnut (Arachis hypogaea L.). Front. Plant Sci. 8, 794 (2017).

4) Juhaimi, F.A.; Ghafoor, K.; Babiker, E.E.; Ozcan, M.M.; Aadiamo, O.Q.; Alsawmahi, O.N. Influence of storage and roasting on the quality properties of kernel and oils of raw and roasted peanuts. J. Oleo Sci. 67, 755762 (2018).

5) Zhao, Z.; Chen, F.; Hao, L. Effect of physiochemical factors and peanut varieties on the charge stability of oil bodies extracted by aqueous method. J. Oleo Sci. 68, 297-306 (2019).

6) Sarath, K.L.L.; Goneli, A.L.D.; Filho, C.P.H.; Masetto, T.E.; Oba, G.C. Physiological potential of peanut seeds submitted to drying and storage. J. Seed Sci. 38, 233240 (2016).

7) Lewis, M.A.; Trabelsi, S.; Nelson, S.O. Using microwave sensing to investigate kernel moisture content at the front and back of semitrailers during peanut drying. Appl. Eng. Agric. 33, 611-617(2017).

8) Liu, R.; Lu, M.; Wang, R.; Wang, S.; Chang, M.; Jin, Q.; Wang, X. Degradation of aflatoxin $\mathrm{b}_{1}$ in peanut meal by electron beam irradiation. Int. J. Food Prop. 21, 892901 (2018).

9) Zhang, S.; Zhou, L.; Ling, B.; Wang, S. Dielectric properties of peanut kernels associated with microwave and radio frequency drying. Biosys. Eng. 145, 108117 (2016).

10) Lewis, M.A.; Trabelsi, S.; Nelson, S.O. Estimating energy costs of nonbeneficial dryer operation by using a peanut drying monitoring system. Appl. Eng. Agric. 34, 491-496 (2018).

11) Lewis, M.A.; Trabelsi, S.; Nelson, S.O. Assessment of real-time, in-shell kernel moisture content monitoring with a microwave moisture meter during peanut drying. Appl. Eng. Agric. 30, 649-656 (2014).

12) Goneli, A.L.D.; Araujo, W.D.; Hartmann Filho, C.P.; Martins, E.A.S.; Oba, G.C. Drying kinetics of peanut kernels in thin layers. Engenharia Agrícola 37, 9941003 (2017).

13) Yang, C.Y.; Fon, D.S.; Lin, T.T. Simulation and validation of thin layer models for peanut drying. Drying Technol. 25, 1515-1526(2007).

14) Chen, D.Y.; Zhang, D.;Zhu, X.F. Heat/mass transfer characteristics and nonisothermal drying kinetics at the first stage of biomass pyrolysis. J. Therm. Anal. Calorim. 109, 847-854(2011).

15) Idrus, N.F.M.; Zzaman, W.; Yang, T.A.; Easa, A.M.;
Sharifudin, M.S.; Noorakmar, B.W.; Jahurul, M.H.A. Effect of superheated-steam roasting on physicochemical properties of peanut (Arachis hypogea) oil. Food Sci. Biotechnol. 26, 911-920 (2017).

16) Hu, H.; Liu, H.; Shi, A.; Liu, L.; Fauconnier, M.L.; Wang, Q. The effect of microwave pretreatment on micronutrient contents, oxidative stability and flavor quality of peanut oil. Molecules 24, 1-12(2018).

17) Ji, H.; Dong, S.; Han, F.; Li, Y.; Chen, G.; Li, L.; Chen, Y. Effects of dielectric barrier discharge $(\mathrm{dbd})$ cold plasma treatment on physicochemical and functional properties of peanut protein. Food Bioprocess Tech. 11, 344-354 (2017).

18) Aidee, S.R.; Sayra, R.B.; José, R.R.; Bertha, B.D.; Sergio O., S.S.; Cristina, C.H. Phosphoesterification of soybean and peanut proteins with sodium trimetaphosphate (stmp): Changes in structure to improve functionality for food applications. Food Chem. 260, 299-305 (2018).

19) Li, P.; Wen, J.; Ma, X.; Lin, F.; Jiang, Z.; Du, B. Structural, functional properties and immunomodulatory activity of isolated inca peanut (Plukenetia volubilis L.) seed albumin fraction. Int. J. Biol. Macromol. 118, 1931-1941 (2018).

20) Arise, A.K.; Nwachukwu, I.D.; Aluko, R.E.; Amonsou, E.O. Structure, composition and functional properties of storage proteins extracted from bambara groundnut (Vigna subterranea) landraces. Int. J. Food Sci. Technol. 52, 1211-1220(2017).

21) Gong, K.J.; Shi, A.M.; Liu, H.Z.; Liu, L.; Hu, H.; Adhikari, B.; Wang, Q. Emulsifying properties and structure changes of spray and freeze-dried peanut protein isolate. J. Food Eng. 170, 33-40 (2016).

22) He, X.H.; Liu, H.Z.; Liu, L.; Zhao, G.L.; Wang, Q.; Chen, Q.L. Effects of high pressure on the physicochemical and functional properties of peanut protein isolates. Food Hydrocoll. 36, 123-129 (2014).

23) Willian, D.A.; Goneli, A.L.D.; Souza, C.M.A.d.; Gonçalves, A.A.; Vilhasanti, H.C.B. Physical properties of peanut kernels during drying. Rev. Bras. Eng. Agr. Amb. 18, 279-286 (2014).

24) Araujo, W.D.; Goneli, A.L.D.; Orlando, R.C.; Martins, E.A.S.; Hartmann Filho, C.P. Propriedades f sicas dos frutos de amendoim durante a secagem. Revista Caatinga 28, 170-180 (2015).

25) AOAC. Moisture measurement-peanuts s410.2. American Society of Agricultural and Biological Engineers (2010).

26) Butts, C.L.; Lamb, M.C.; Sorensen, R.B.; Chen, S. Oven drying times for moisture content determination of single peanut kernels. Transactions of the ASABE 57, 579-584 (2014).

27) Mortimer, D.N.; Shepherd, M.J.; Gilbert, J.; Clark, C. Enzyme-linked immunosorbent (elisa) determination 
of aflatoxin $\mathrm{b}_{1}$ in peanut butter: Collaborative trial. Food Addit. Contam. 5, 601-608(1988).

28） Jamdar, S.N.; Rajalakshmi, V.; Pednekar, M.D.; Juan, F.; Yardi, V.; Sharma, A. Influence of degree of hydrolysis on functional properties, antioxidant activity and ace inhibitory activity of peanut protein hydrolysate. Food Chem. 121, 178-184(2010).

29) Lykomitros, D.; Den Boer, L.; Hamoen, R.; Fogliano, V.; Capuano, E. A comprehensive look at the effect of processing on peanut (Arachis spp.) texture. J. Sci. Food Agric. 98, 3962-3972 (2018).

30) Hanusz, Z.; Ślaska-Grzywna, B.; Blicharz-Kania, A.; Klimek, K.; Andrejko, D.; Stoma, M. Multivariate analysis of textural properties of butternut squash during thermal treatment. J. Food Meas. Charact. 12, 29642970 (2018).

31) Muniyappan, V.K.; Tamilmani, E.; Desikan, R.; Ranganathan, U. Influence of groundnut seed viability on biodiesel feedstock quality. Ind. Crop Prod. 140, 111697 (2019).

32） Yang, J.; Zhao, R.; Song, L.; Yin, J.; You, Y.; Sun, C.; Li, Y. Optimized ultrasonic-assisted extraction of aflatoxin $b_{1}$ in peanuts with response surface methodology. Anal. Lett. 50, 629-640 (2016).

33) Neme, K.; Mohammed, A. Mycotoxin occurrence in grains and the role of postharvest management as a mitigation strategies. A review. Food Control. 78, 412425 (2017).

34) Mahatma, M.K.; Thawait, L.K.; Bishi, S.K.; Khatediya, N.; Rathnakumar, A.L.; Lalwani, H.B.; Misra, J.B. Nutritional composition and antioxidant activity of spanish and virginia groundnuts (Arachis hypogaea L.) : A comparative study. J. Food Sci Tech. 53, 2279-2286 (2016).

35) Hu, H.; Liu, H.; Shi, A.; Liu, L.; Fauconnier, M.L.; Wang, Q. The effect of microwave pretreatment on micronutrient contents, oxidative stability and flavor quality of peanut oil. Molecules 24, E62 (2018).

36) Ren, C.; Huang, G.; Wang, S.; Xiao, J.; Xiong, X.; Wang, H.; Liu, Y. Influence of atmospheric pressure argon plasma treatment on the quality of peanut oil. Eur. $J$. Lipid Sci. Tech. 119, 1-13(2017).

37) Xu, L.; Yu, X.; Liu, L.; Li, M.; Zhang, R. A rapid method for evaluating the edible oil oxidative stability during ambient storage by ftir spectroscopy using a mesh cell. Anal. Methods 8, 5117-5122 (2016).

38） Zhu, M.; Wen, X.; Zhao, J.; Liu, F.; Ni, Y.; Ma, L.; Li, J. Effect of industrial chemical refining on the physicochemical properties and the bioactive minor components of peanut oil. J. Am. Oil Chem. Soc. 93, 285$294(2015)$.

39) Liu, K.; Li, Y.; Chen, F.; Yong, F. Lipid oxidation of brown rice stored at different temperatures. Int. J. Food Sci. Tech. 52, 188-195(2017).

40) Martín, M.P.; Asensio, C.M.; Nepote, V.; Grosso, N.R. Improving quality preservation of raw peanuts stored under different conditions during a long-term storage. Eur. J. Lipid Sci. Tech. 120, 1800150 (2018).

41) Abbas Ali, M.; Anowarul Islam, M.; Othman, N.H.; Noor, A.M. Effect of heating on oxidation stability and fatty acid composition of microwave roasted groundnut seed oil. J. Food Sci. Technol. 54, 4335-4343 (2017).

42) Ziegler, V.; Ferreira, C.D.; Hoffmann, J.F.; de Oliveira, M.; Elias, M.C. Effects of moisture and temperature during grain storage on the functional properties and isoflavone profile of soy protein concentrate. Food Chem. 242, 37-44 (2018).

43) Lee, H.J.; Kim, J.H.; Ji, D.S.; Lee, C.H. Effects of heating time and temperature on functional properties of proteins of yellow mealworm larvae (Tenebrio molitor L.) . Korean J. Food Sci. An. 39, 296-308 (2019).

44） Guo, F.; Xiong, Y.L.; Qin, F.; Jian, H.; Huang, X.;Chen, J. Surface properties of heat-induced soluble soy protein aggregates of different molecular masses. J. Food Sci. 80, C279-287 (2015).

45) Jain, A.; Prakash, M.; Radha, C. Extraction and evaluation of functional properties of groundnut protein concentrate. J. Food Sci. Tech. 52, 6655-6662(2015). 